\title{
The Last Breath
}

\author{
Adam Faletsky ${ }^{1}$
}

Received: 18 November 2020 / Accepted: 22 December 2020/Published online: 12 January 2021

(C) Academic Psychiatry 2021

Young and eager at the age of 18, I signed up for my university's emergency medical service. One semester of courses was all it took before I was able to ride as a crewmember in my campus ambulance. On one of my first shifts, I noticed that something wasn't right-the radios, usually filled with chatter, were eerily silent. As I approached the patient's room, I heard a panicked voice calling for advanced life support to meet us on scene. I opened the door to find my colleague cutting the rope from the neck of a boy my age.

\section{Surprise.}

Fear.

Indecision.

Sadness.

I ran over and began to run the code with my colleague. For thirty minutes, we continued the cycle: compressions, ventilations, shock, repeat.

I gave him the last breath he would ever take.

When advanced life support arrived to call the time of death, I began to mourn. I mourned for the young life taken, for the mother that lost her son, and for the darkness looming in my university's community.

I never expected to be confronted with such a troubling and saddening situation as a sophomore in college. My peers assured me that I would be a stronger person in

Adam Faletsky

adam.faletsky@tufts.edu

1 Tufts University School of Medicine, Boston, MA, USA the end, that this experience would make me a better doctor. In reality, I felt like I had failed. For weeks, no, months, I thought about that young man every day. I thought about what I could have done differently and what I would do if confronted with the same situation again. I had nightmares and could not open doors without holding my breath.

"Maybe being a doctor isn't your forte," my friends and family members would tell me. This comment surprised me the most. What kind of doctor would I be if I had not responded in such a way? Medicine is more than just dealing with bloody wounds and dying people. It's about learning from your experiences and getting better at treating your patients. It's about being there for someone when they need it the most. I'm not becoming a doctor just to save lives; I'm becoming a doctor to make a difference.

Fast forward 5 years. I'm a newly minted third-year medical student on my psychiatry rotation heading to the ED for an admission: an attempted suicide. Again, my nervousness was palpable, but I composed myself. With a final breath, I entered the patient's room.

Sadness.

Indecision.

Fear.

Surprise.

He was a young man, about my age, surrounded by friends and family. His mother had noticed he was not returning her calls, and ultimately found him in a bathtub with razors at his side. She got to him before it was too late. I came to realize that I could now do what would have been impossible to do before. I made it my mission to give this young man the attention he needed and deserved during his inpatient stay. Through several weeks of 
one-on-one meetings, family therapy, and pharmaceutical intervention, he confided in me a desire to live.

Some learning in medicine, as in life, is truly trial by fire. Knowing the experiences I have had, I can only hope that one day, in the not too distant future, I will take these experiences in stride as they guide me through residency and beyond. In truth, our most profound learning in medicine is epitomized by far more than a simple lesson plan — rather, it is embodied by breaths taken, minds healed, lives regained, and differences made.

\section{Compliance with Ethical Standards}

Disclosures The author states that there is no conflict of interest.

Publisher's Note Springer Nature remains neutral with regard to jurisdictional claims in published maps and institutional affiliations. 